\title{
Inverse association between social support and household food insecurity in a metropolitan area of Rio de Janeiro, Brazil
}

\author{
Gabriela dos Santos Interlenghi ${ }^{1}$ and Rosana Salles-Costa ${ }^{2, *}$
}

${ }^{1}$ Post-Graduate Program, Nutrition Institute Josué de Castro, Federal University of Rio de Janeiro, Rio de Janeiro, Brazil: ${ }^{2}$ Department of Public Nutrition, Nutrition Institute Josué de Castro, Federal University of Rio de Janeiro, Carlos Chagas Filho 373, Centro de Ciências da Saúde-Instituto de Nutrição, Bloco J - $2^{\circ}$ andar, CEP 21941-902, Rio de Janeiro/RJ, Brazil

Submitted 15 October 2013: Final revision received 17 June 2014: Accepted 1 August 2014: First published online 10 September 2014

\begin{abstract}
Objective: To verify the association between perceived social support and household food insecurity (HFI).

Design: A cross-sectional survey.

Setting: A population-based study with a representative sample of households from a metropolitan area of Rio de Janeiro, Brazil, conducted in 2010. HFI was estimated with the Brazilian Food Insecurity Scale (EBIA). Social support was assessed using the adapted and validated Brazilian version of the Medical Outcomes Study Social Support Survey. Multinomial logistic regression was used to evaluate the association between social support and HFI, adjusting for potential confounders.

Subjects: Adults ( $n$ 1022) aged 19-60 years old (27\% men, 73\% women) who were responsible for feeding the household.

Results: Individuals with high scores of social support were less likely to experience moderate HFI (OR $=0.96 ; 95 \%$ CI $0.94,0.99)$ and severe HFI (OR=0.96; $95 \%$ CI 0.94, 0.98).

Conclusions: These findings indicate that social support may contribute to reducing HFI in populations vulnerable to poverty. Strategies to increase social relationships should be encouraged in this group to enhance their perceived social support.
\end{abstract}

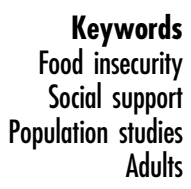

Brazil defines food and nutrition security as: 'the realization of everyone's right to regular and permanent access to quality food in sufficient quantity, without compromising access to other essential needs, based on health-promoting food practices that respect cultural diversity and that are environmentally, culturally, economically and socially sustainable ${ }^{,(1)}$. In this wide and multidimensional definition, the dimension of access to food deserves to be highlighted. When food is not accessed in satisfactory quantity and quality, individuals experience food insecurity $(\mathrm{FI})^{(2)}$. In turn, FI negatively impacts people's lives and is linked to physical $^{(3,4)}$ and mental health damage ${ }^{(5-8)}$, the onset of chronic conditions ${ }^{(9-11)}$ and unhealthy eating patterns ${ }^{(12-15)}$.

Since 2004, the assessment of household food insecurity (HFI) has been included in the major national surveys ${ }^{(16-18)}$, using an FI experience-based scale that was developed by the US Department of Agriculture ${ }^{(19-23)}$ and adapted and validated for the Brazilian context ${ }^{(2,24,25)}$. The first diagnosis of HFI in Brazilian households was provided by the National Household Sample Survey (PNAD) in $2004^{(16)}$.
The 2004 PNAD revealed that $34.8 \%$ of households experienced FI. A similar proportion was observed by the National Demographic and Health of Children and Women Survey (PNDS) in $2006(37.5 \%)^{(17)}$. The latest results, derived from the PNAD in $2009^{(18)}$, indicated that $30.2 \%$ of Brazilian households continue to experience HFI.

HFI is closely related to social indicators ${ }^{(3,16-18,26-28)}$, especially those concerning family income ${ }^{(29-31)}$. However, beyond financial constraints and poverty-related adverse conditions that make families vulnerable to HFI, there are other aspects of people's lives that influence their success in meeting food intake needs ${ }^{(32)}$. A relatively unexplored aspect is the contribution of interpersonal relationships in this context. Some researchers have suggested that interpersonal and community-level social relationships, particularly the resources they provide, would help vulnerable people in handling this adverse condition ${ }^{(33-36)}$.

In fact, interpersonal relationships provide opportunities to experience and improve social support; social support is defined as the level of resources that are 
provided by other people ${ }^{(37)}$ or the degree to which interpersonal relationships serve particular functions ${ }^{(38,39)}$. These functions involve the provision of care, love, trust and empathy; material support; the provision of suggestions, advice and information that could solve problems ${ }^{(39)}$; physical demonstrations of love and affection ${ }^{(40)}$; and the availability of people to engage in pleasurable and leisure activities $^{(39,40)}$. Social support also causes individuals to feel cared for, loved and esteemed ${ }^{(41)}$ and may improve their ability to cope with stressful events ${ }^{(42,43)}$.

Thus, having social support can improve conditions for people with HFI, either through the provision of resources (e.g. food donations or exchange, having someone to cook with) or through beneficial consequences that feeling cared for, loved and belonging to a supportive social network would have to individual perceptions concerning having enough food to a quantitatively and qualitatively feeding. Therefore, believing that social support can improve food and nutrition security and considering that this association has been understudied, the present study aimed to verify the association between social support and HFI in a sample of households from Duque de Caxias, a metropolitan area of Rio de Janeiro, Brazil.

\section{Methods}

\section{Setting and data collection}

The present population-based cross-sectional study was conducted with a representative sample of households from Campos Elíseos, a low-income district of the municipality of Duque de Caxias in the metropolitan area of Rio de Janeiro, Brazil. According to the Brazilian demographic census $^{(44)}$, the district was composed of 290762 residents in 2010, of whom 290612 (99.9\%) lived in 89834 private households. The present study derives from a major survey, the Pesquisa SANDUC, which is the second round of a panel study that was conducted between April and December of 2010. The region was first evaluated in 2005. Details on the study, data collection and data quality control are published elsewhere ${ }^{(29)}$.

An inverse probabilistic cluster sampling method was conducted in three stages. In the first stage, seventy-five census tracts were selected from the 322 that composed Campos Elíseos at the time of data collection. A census tract is a territorial unit for census control and data collection; tracts are composed of continuous areas that align with political-administrative boundaries, urban and rural legal divisions and other territorial structures ${ }^{(44)}$. The sample was composed by 1125 private households, considering an extreme regional poverty prevalence of $14.5 \%$ and that it is strongly correlated with HFI in Brazil ${ }^{(32)}$. As a result of the major survey's objectives, the same seventy-five census tracts that were selected for the 2005 study were maintained for 2010. At that time, the tracts were systematically selected with probabilities that were proportional to the number of private households. The second stage comprised an equiprobable random selection of 1125 households (fifteen residences per tract). The third stage included the selection of participants, considering one participant for each stratum of age (children, adolescents and adults). The study population in the present study comprised adults aged 19-60 years who were the householder or the householder's partner (or another individual for single families) and who were responsible for feeding the household and had responded to the FI module.

From the fixed sample size of 1125 households, data were obtained from 1121 households (99.6\%). A total of 1031 individuals met the eligibility criteria for the present study. However, nine individuals were excluded due to inconsistencies on the social support questions. Thus, the final sample comprised 1022 adults (27\% male and $73 \%$ female).

The interview team included four nutritionists and eight local residents who had graduated from high school. The interviewers were previously trained $(40 \mathrm{~h})$ to administer the Brazilian Food Insecurity Scale (EBIA), social support and socio-economic and demographic questionnaires by researchers with expertise in population surveys and questionnaire administration. The collected data were checked by a supervisor. All participants provided signed informed consent. The research was approved by the ethics committee of the Federal University of Rio de Janeiro (number 73/2009; protocol number 01/2009).

\section{Household food insecurity}

The EBIA, an adapted and validated version ${ }^{(2,24,25)}$ of the Household Food Security Survey Module (HFSSM) $^{(45)}$, was used to assess HFI and had a Cronbach's $\alpha$ of 0.88 among this sample, indicating high reliability. The EBIA is composed of fifteen 'yes/no' items, seven of which relate to family members under 18 years old. Therefore, households with children/adolescents (Child) answered fifteen questions and households without children/adolescents (Adult) answered eight questions. A score of 1 was given for each positive answer and an FI score was computed for each household (Child $=0-15$, Adult $=0-8$ ). Households were then classified into four levels of FI: (i) food security (FS; score $=0$ ); (ii) mild FI - fear of suffering FI in the near future (Child=1-5, Adult=1-3); (iii) moderate FI - restriction of the quantity of food for the family (Child $=6-10$, Adult $=4-6$ ); and (iv) severe FI - hunger among adults and/or children in the family (Child $=11-15$, Adult $=7-8)^{(2)}$.

\section{Social support}

The Brazilian adapted ${ }^{(46)}$ and validated ${ }^{(47)}$ version of the Medical Outcomes Study Social Support Survey (MOS-SSS) ${ }^{(39)}$ was used to assess social support and had a Cronbach's $\alpha$ of 0.93 among this sample, indicating high reliability. The instrument is a nineteen-item scale that was designed 
to assess individual perceptions of social support in five dimensions: (i) material (the provision of practical resources and tangible support; four questions); (ii) emotional (the ability of a social network to meet individual needs regarding emotional problems; four questions); (iii) informational (guidance/feedback that can help in problem solving; four questions); (iv) affective (physical demonstrations of love and affection; three questions); and (v) positive social interaction (relying on people to relax and have fun; four questions).

For each scale item, people were asked to indicate how often each type of support was available when the support was needed. The five-point scale response options ranged from 'never' (1 point) to 'always' (5 points). A score for each social support dimension was computed by adding up the points for each item of the corresponding dimension. Following Chor et al. ${ }^{(46)}$, the scores for each dimension were transformed so that the lowest possible score was 20 and the highest possible score was 100, with higher scores indicating a more frequent availability of different types of social support. Total social support was also obtained by the sum of the points on the nineteen-item scale. Total social support scores vary from 19 to 95 points, where 19 indicates infrequent availability of overall social support and 95 indicates frequent availability of overall social support (i.e. the strongest perception of having overall social support when needed).

\section{Socio-economic and demographic characteristics}

Potential confounders for the relationship between social support and HFI were assessed by a structured questionnaire. These variables were: (i) monthly per capita family income (total family income divided by the number of residents who depended on this income, in multiples of the Brazilian minimum wage in 2010); (ii) number of household members; (iii) water supply (public water supply as the reference category); (iv) household water treatment (presence of a water filter in the household); and (iv) gender; (v) age; (vi) family role (being the householder as the reference category); (vii) marital status (being married/ common-law as the reference category); (viii) educational level (years of study); and (ix) job status (remunerated activity as the reference category) of the assessed adult.

\section{Data analysis}

Proportion distributions and their respective 95\% confidence intervals were estimated for socio-economic and demographic characteristics. Mean values and their corresponding standard errors were estimated for the social support scores. The $\chi^{2}$ test for categorical variables and Student's $t$ test for continuous variables were used to examine the difference in their prevalence by HFI (food secure $v$. food insecure), considering a $P$ value $\leq 0.05$ for statistical significance. Multinomial logistic regression was used to test the association of social support (independent variable) and socio-economic and demographic factors (potential confounders) with HFI (outcome variable; 'food security' was used as the reference category). The socio-economic and demographic variables included in the multinomial logistic regression were selected based on theoretical and empirical considerations after exploring their univariate correlations with HFI, using a $P$ value $<0 \cdot 20$ for screening for possible interactions. The results were expressed as odds ratio and the corresponding 95\% confidence interval. Findings were considered statistically significant if the $95 \%$ confidence interval did not include the value of 1.0. The database was developed and recorded in duplicate by previously trained staff and the data were analysed using the statistical software package STATA version 11.0 (2009).

\section{Results}

More than half of the households were classified with FS, $30 \%$ had mild FI, $8.9 \%$ had moderate FI and $3.5 \%$ had severe FI (data not shown). Only $23.9 \%$ of the households had a monthly per capita family income higher than or equal to the minimum wage, and $34.4 \%$ lived on a monthly per capita family income below half the minimum wage. Families with HFI reported lower incomes than families with FS $(P<0.0001)$. Most households were composed of one to three members $(60.5 \%)$, and households with HFI had a greater number of occupants $(P=0.0024)$. A total of $40.1 \%$ of households did not have access to the public water supply. Half of the households with FS had water treatment, but only $27.5 \%$ of households with FI had water treatment $(P<0.0001)$. More than $90 \%$ of the adults surveyed were the householder or his/her partner. Respondents were generally married/common-law (66.9\%) and had some remunerated activity (61.8\%). Food-insecure individuals had fewer years of education than food-secure individuals $(P=0.0062)$. Affective support was the dimension with the highest score in both food-secure (93.8, SE 0.69) and food-insecure (87.4, SE 1.24) individuals. Emotional support had the lowest score. Individuals with HFI had significantly $(P<0.008)$ lower scores for all dimensions of social support, which shows that their perceptions of having different types of support when they were needed were lower than among individuals with FS (Table 1).

The multinomial logistic regression results are shown in Table 2. The results of the unadjusted analysis revealed that material and affective support were inversely associated with mild and moderate FI; emotional support was inversely associated with moderate and severe FI; and informational, positive social interaction and total social support were inversely associated with all HFI levels. Moreover, monthly per capita family income below half the minimum wage and the absence of household water treatment were both positively associated with all FI levels. Additionally, a higher number of household members was positively correlated with mild and moderate FI, and not 
Table 1 Prevalence of household and individual socio-economic and demographic characteristics and mean of perceived social support by food security status, Duque de Caxias, Rio de Janeiro, Brazil, 2010

\begin{tabular}{|c|c|c|c|c|c|c|c|}
\hline \multirow[b]{2}{*}{ Study variable } & \multicolumn{2}{|c|}{$\begin{array}{l}\text { Food security } \\
\text { (n 559; } 54.7 \%)\end{array}$} & \multicolumn{2}{|c|}{$\begin{array}{l}\text { Household food insecurity } \\
(n 463 ; 45.3 \%)\end{array}$} & \multicolumn{2}{|c|}{$\begin{array}{c}\text { Total } \\
(n \text { 1022) }\end{array}$} & \multirow[b]{2}{*}{$P$ value } \\
\hline & $\%$ & $95 \% \mathrm{Cl}$ & $\%$ & $95 \% \mathrm{Cl}$ & $\%$ & $95 \% \mathrm{Cl}$ & \\
\hline \multicolumn{8}{|l|}{ Household characteristics } \\
\hline \multicolumn{8}{|l|}{ Monthly per capita family income† $(n 854)^{*}$} \\
\hline$<1 / 4$ minimum wage & $2 \cdot 3$ & $1.4,3.9$ & $5 \cdot 8$ & $4 \cdot 2,8 \cdot 0$ & 8.2 & $6 \cdot 2,10 \cdot 7$ & \multirow{4}{*}{$<0.0001$} \\
\hline $1 / 4-1 / 2$ minimum wage & 9.5 & $7 \cdot 1,12 \cdot 6$ & $16 \cdot 7$ & $13 \cdot 2,20 \cdot 9$ & $26 \cdot 2$ & $22 \cdot 1,30 \cdot 8$ & \\
\hline $1 / 2-1$ minimum wage & 25.9 & $21 \cdot 8,30 \cdot 4$ & $15 \cdot 8$ & $12 \cdot 5,19 \cdot 8$ & $41 \cdot 7$ & $37 \cdot 0,46 \cdot 5$ & \\
\hline$\geq 1$ minimum wage & $19 \cdot 1$ & $15 \cdot 8,23 \cdot 0$ & 4.8 & $3 \cdot 2,7 \cdot 2$ & 23.9 & $20 \cdot 2,28 \cdot 1$ & \\
\hline \multicolumn{8}{|l|}{ Number of household members $(n 1022)^{\star}$} \\
\hline 1-3 people & 38.2 & $33 \cdot 9,42 \cdot 7$ & $22 \cdot 3$ & $18 \cdot 8,26 \cdot 1$ & 60.5 & $55 \cdot 9,64.9$ & \multirow[t]{2}{*}{0.0024} \\
\hline$>4$ people & $19 \cdot 3$ & $15 \cdot 9,23 \cdot 2$ & 20.2 & $16 \cdot 6,24 \cdot 3$ & 39.5 & $35.1,44 \cdot 1$ & \\
\hline \multicolumn{8}{|l|}{ Water supply $(n 1020)^{*}$} \\
\hline Public net & $36 \cdot 4$ & $32 \cdot 1,40 \cdot 9$ & 23.6 & $19 \cdot 8,27 \cdot 7$ & 59.9 & $55 \cdot 5,64 \cdot 1$ & \multirow[t]{2}{*}{0.1427} \\
\hline Other types & $21 \cdot 7$ & $18 \cdot 3,25 \cdot 4$ & $18 \cdot 4$ & $15 \cdot 3,21 \cdot 9$ & $40 \cdot 1$ & $35 \cdot 9,44 \cdot 5$ & \\
\hline \multicolumn{8}{|l|}{ Household water treatment $(n 991)^{\star}$} \\
\hline Yes & $50 \cdot 1$ & $45 \cdot 5,54 \cdot 7$ & $27 \cdot 5$ & $23 \cdot 6,31 \cdot 8$ & $77 \cdot 6$ & $73 \cdot 6,81 \cdot 2$ & \multirow[t]{2}{*}{$<0.0001$} \\
\hline No & $8 \cdot 3$ & $6 \cdot 0,11 \cdot 4$ & 14.0 & $11 \cdot 3,17 \cdot 3$ & 22.4 & $18 \cdot 8,26 \cdot 4$ & \\
\hline \multicolumn{8}{|l|}{ Sample adults' characteristics } \\
\hline $\operatorname{Sex}(n 1022)^{*}$ & & & & & & & \\
\hline Male & 18.5 & $15 \cdot 0,22 \cdot 6$ & $15 \cdot 4$ & $12 \cdot 1,19 \cdot 3$ & 33.9 & $29 \cdot 3,38 \cdot 4$ & \multirow[t]{2}{*}{0.3852} \\
\hline Female & 39.0 & $34.8,43.5$ & $27 \cdot 1$ & $23 \cdot 4,31 \cdot 2$ & 66.1 & $61 \cdot 6,70 \cdot 7$ & \\
\hline \multicolumn{8}{|l|}{ Age $(n 1022)^{*}$} \\
\hline $19-29.9$ years & 12.5 & $9 \cdot 5,16 \cdot 3$ & $7 \cdot 1$ & $5 \cdot 4,9 \cdot 2$ & $19 \cdot 6$ & $16 \cdot 2,23 \cdot 6$ & \multirow[t]{4}{*}{0.3418} \\
\hline $30-39.9$ years & 20.6 & $17 \cdot 0,24 \cdot 7$ & 17.9 & $14.5,21.9$ & 38.5 & $34.0,43.1$ & \\
\hline $40-49.9$ years & 13.0 & $10 \cdot 6,15 \cdot 9$ & 8.5 & $6 \cdot 2,11.4$ & 21.5 & $18 \cdot 2,25 \cdot 2$ & \\
\hline $50-60$ years & 11.4 & $9 \cdot 1,14 \cdot 2$ & $9 \cdot 0$ & $6 \cdot 7,12 \cdot 1$ & $20 \cdot 4$ & $17 \cdot 1,24 \cdot 1$ & \\
\hline \multicolumn{8}{|l|}{ Family role $(n 1022)^{*}$} \\
\hline Head of family & 34.4 & $30 \cdot 3,38 \cdot 8$ & $25 \cdot 7$ & $21 \cdot 9,29 \cdot 8$ & $60 \cdot 1$ & $55 \cdot 5,64.5$ & \multirow{3}{*}{0.8911} \\
\hline Head of family's partner & 19.2 & $15 \cdot 9,23 \cdot 1$ & 14.4 & $11.5,18.0$ & 33.7 & $29.5,38 \cdot 1$ & \\
\hline Head of family's son or other & 3.9 & $2 \cdot 3,6 \cdot 3$ & $2 \cdot 4$ & $1.1,4.8$ & $6 \cdot 2$ & $4.1,9.3$ & \\
\hline \multicolumn{8}{|l|}{ Marital status $(n 1017)^{*}$} \\
\hline Married/living common-law & 39.8 & $35 \cdot 5,44 \cdot 3$ & $27 \cdot 1$ & $23 \cdot 4,31 \cdot 1$ & 66.9 & $62 \cdot 2,71 \cdot 2$ & \multirow{2}{*}{0.2153} \\
\hline Not married//iving common-law & $17 \cdot 6$ & $14 \cdot 3,21.5$ & $15 \cdot 5$ & $12 \cdot 1,19 \cdot 6$ & $33 \cdot 1$ & $28 \cdot 8,37 \cdot 8$ & \\
\hline Years of education $(n 1000)^{*}$ & & & & & & & \\
\hline $0-8$ years & $39 \cdot 4$ & $35 \cdot 0,44.0$ & $34 \cdot 3$ & $30 \cdot 1,38.9$ & 73.8 & $69.7,77.5$ & 0.0062 \\
\hline$\geq 8$ years & $17 \cdot 7$ & $14 \cdot 6,21 \cdot 3$ & 8.6 & $6.4,11 \cdot 3$ & $26 \cdot 2$ & $22 \cdot 5,30 \cdot 3$ & \\
\hline Job status $(n 1011)^{*}$ & & & & & & & \\
\hline With some job & $35 \cdot 2$ & $30.9,39.6$ & $26 \cdot 6$ & $22 \cdot 7,30 \cdot 9$ & 61.8 & $57 \cdot 3,66 \cdot 0$ & 0.3689 \\
\hline Without any job & $23 \cdot 3$ & $19 \cdot 7,27 \cdot 4$ & 14.9 & $12 \cdot 2,18 \cdot 0$ & $38 \cdot 2$ & $34 \cdot 0,42 \cdot 7$ & \\
\hline & Mean & SE & Mean & SE & Mean & SE & \\
\hline Perceived social support & & & & & & & \\
\hline Material support $(n \text { 1022) })^{\star}$ & $84 \cdot 1$ & $1 \cdot 11$ & $77 \cdot 0$ & 1.65 & $81 \cdot 1$ & 0.97 & $<0.0001$ \\
\hline Emotional support ( $n$ 1022)* & 80.5 & $1 \cdot 30$ & 76.4 & 1.51 & 78.9 & 0.99 & 0.040 \\
\hline Informational support $(n$ 1022)* & 82.9 & 1.15 & $77 \cdot 2$ & 1.47 & $80 \cdot 4$ & 0.93 & 0.002 \\
\hline Affective support $(n \text { 1022) })^{\star}$ & 93.8 & 0.69 & 87.4 & 1.24 & 91.1 & 0.67 & $<0.0001$ \\
\hline Positive social interaction support $(n$ 1022)* & 89.5 & 0.84 & $82 \cdot 1$ & 1.36 & $86 \cdot 3$ & 0.77 & $<0.0001$ \\
\hline Total social support $(n \text { 1022) })^{*}$ & 81.5 & 0.80 & 75.6 & $1 \cdot 14$ & 79.0 & 0.68 & $<0.0001$ \\
\hline
\end{tabular}

*Different losses due to non-responses.

†Considering the value of the Brazilian minimum wage in the year 2010 ( $\$ \mathrm{R} 510.00$ or $\$$ US $288 \cdot 16$, considering the conversion rate $\$ \mathrm{R} 1=\$ \mathrm{US} 1 \cdot 77$ from July 2010).

having access to the public water supply was positively associated with mild FI. Lower educational levels were also positively correlated with severe FI.

In the adjusted model, the following inverse associations remained: material support and moderate FI; affective support and mild and moderate FI; emotional support and severe FI; informational support and severe FI; and positive social interaction and all FI levels. Overall, individuals with higher scores of social support were less likely to experience HFI. Family income remained strongly associated with HFI. Families with a monthly per capita income of less than half the minimum wage were more likely to experience more severe levels of FI, with OR varying from $3.47(95 \%$ CI $2 \cdot 12,5 \cdot 67)$ for mild FI to 5.31 (95\% CI 1.34, 21.03) for severe FI. The absence of water treatment remained associated with mild and moderate FI, and not having access to the public water supply was associated with mild FI. Additionally, the adjusted model showed that the households of respondents with 8 years of education or less were almost ten times more likely to experience FI than the households of respondents with more education (Table 2). 
Table 2 Relationships among food insecurity, social support and socio-economic and demographic factors (multinomial logistic regression, considering food security as the reference category), Duque de Caxias, Rio de Janeiro, Brazil, 2010

\begin{tabular}{|c|c|c|c|c|c|c|c|c|c|c|c|c|}
\hline \multirow[b]{3}{*}{ Study variables } & \multicolumn{6}{|c|}{ Food insecurity (unadjusted model) } & \multicolumn{6}{|c|}{ Food insecurity (adjusted model) } \\
\hline & \multicolumn{2}{|r|}{ Mild } & \multicolumn{2}{|r|}{ Moderate } & \multicolumn{2}{|r|}{ Severe } & \multicolumn{2}{|r|}{ Mild } & \multicolumn{2}{|c|}{ Moderate } & \multicolumn{2}{|r|}{ Severe } \\
\hline & OR & $95 \% \mathrm{Cl}$ & OR & $95 \% \mathrm{Cl}$ & OR & $95 \% \mathrm{Cl}$ & OR & $95 \% \mathrm{Cl}$ & OR & $95 \% \mathrm{Cl}$ & OR & $95 \% \mathrm{Cl}$ \\
\hline \multicolumn{13}{|l|}{ Social support } \\
\hline Material support* & 0.98 & $0.97,0.99$ & 0.97 & $0.95,0.98$ & 0.98 & $0.95,1.00$ & 0.99 & $0.98,1.00$ & 0.97 & $0.96,0.99$ & - & - \\
\hline Emotional support ${ }^{\star}$ & 0.99 & $0.98,1.00$ & 0.97 & $0.96,0.99$ & 0.98 & $0.96,0.99$ & - & - & 0.98 & $0.96,1.00$ & 0.98 & $0.96,0.99$ \\
\hline Informational support* & 0.98 & $0.97,0.99$ & 0.98 & $0.96,0.99$ & 0.96 & $0.94,0.98$ & 0.99 & $0.98,1.00$ & 0.98 & $0.96,1.00$ & 0.96 & $0.93,0.99$ \\
\hline Affective support ${ }^{\star}$ & 0.97 & $0.95,0.98$ & 0.96 & $0.94,0.98$ & 0.97 & $0.95,1.00$ & 0.97 & $0.96,0.99$ & 0.97 & $0.94,0.99$ & - & - \\
\hline $\begin{array}{l}\text { Positive social interaction } \\
\text { support }^{\star}\end{array}$ & 0.98 & $0.96,0.99$ & 0.97 & $0.95,0.98$ & 0.96 & $0.94,0.98$ & 0.98 & $0.97,0.99$ & 0.97 & $0.95,0.98$ & 0.96 & $0.94,0.98$ \\
\hline Total social support & 0.98 & $0.96,0.99$ & 0.96 & $0.94,0.98$ & 0.96 & $0.94,0.98$ & 0.98 & $0.97,1.00$ & 0.96 & $0.94,0.99$ & 0.96 & $0.94,0.98$ \\
\hline \multicolumn{13}{|c|}{ Monthly per capita familiar income $†$} \\
\hline$<1 / 2$ minimum wage & 3.54 & $2.25,5.55$ & $6 \cdot 65$ & $2 \cdot 74,16.09$ & $6 \cdot 39$ & $1.96,20.75$ & 3.47 & $2 \cdot 12,5 \cdot 67$ & $4 \cdot 34$ & $1.68,11.22$ & $5 \cdot 31$ & $1.34,21.03$ \\
\hline$\geq 1 / 2$ minimum wage & 1.00 & Ref. & 1.00 & Ref. & 1.00 & Ref. & 1.00 & Ref. & 1.00 & Ref. & 1.00 & Ref. \\
\hline \multicolumn{13}{|c|}{ Number of household members } \\
\hline 1-3 people & 1.00 & Ref. & 1.00 & Ref. & 1.00 & Ref & - & - & 1.00 & Ref. & - & - \\
\hline$\geq 4$ people & 1.51 & $0.99,2.29$ & $2 \cdot 92$ & $1 \cdot 42,6 \cdot 01$ & $2 \cdot 31$ & $0 \cdot 86,6 \cdot 18$ & - & - & $1 \cdot 84$ & $0.78,4.33$ & - & - \\
\hline \multicolumn{13}{|l|}{ Water supply } \\
\hline Public net & 1.00 & Ref. & 1.00 & Ref. & 1.00 & Ref. & 1.00 & Ref. & - & - & - & - \\
\hline Other types & 1.52 & $1 \cdot 02,2 \cdot 27$ & 0.84 & $0.41,1.69$ & 0.96 & $0.37,2.46$ & 1.66 & $1.06,2.60$ & - & - & - & - \\
\hline \multicolumn{13}{|l|}{ Household water treatment } \\
\hline Yes & 1.00 & Ref. & 1.00 & Ref. & 1.00 & Ref. & 1.00 & Ref. & 1.00 & Ref. & $1 \cdot 0$ & Ref. \\
\hline No & 2.45 & $1.47,4.07$ & 5.48 & $2 \cdot 65,11 \cdot 33$ & $4 \cdot 13$ & $1.52,11.22$ & $2 \cdot 01$ & $1 \cdot 16,3 \cdot 46$ & 4.61 & $2.09,10.19$ & 2.40 & $0.85,6.78$ \\
\hline \multicolumn{13}{|c|}{ - } \\
\hline $0-8$ years & 1.46 & $0.93,2.29$ & $2 \cdot 74$ & $0.95,7.88$ & 11.86 & $1.53,91.59$ & - & - & - & - & $9 \cdot 83$ & $1 \cdot 20,80 \cdot 30$ \\
\hline$\geq 8$ years & 1.00 & Ref. & 1.00 & Ref. & 1.00 & Ref. & - & - & - & - & 1.00 & Ref. \\
\hline
\end{tabular}

Ref., reference category.

${ }^{*}$ Non-conditional multinomial logistic regression (i.e. dimensions were rotated separately in the adjusted model).

†Considering the value of the Brazilian minimum wage in the year 2010 (\$R $510 \cdot 00$ or $\$$ US $288 \cdot 16$, considering the conversion rate $\$ \mathrm{R} 1=\$ \mathrm{US} 1 \cdot 77$ from July 2010).

\section{Discussion}

These findings show that a significant portion of the families lived in a context of poverty, low educational levels in adults (usually the head of the household or the individual responsible for feeding) and limited access to treated water or the public water supply. These unfavourable living conditions were associated with HFI, which had a high prevalence in the sampled population. These findings revealed an independent and inverse association between social support and HFI in which stronger perceptions of social support were associated with lower likelihoods of experiencing FI. This association remained despite other factors more strongly related to a family's perceptions of having enough access to food (e.g. family income and access to the public water supply). Using the findings from the 2009 PNAD ${ }^{(18)}$, families from Campos Elíseos, Duque de Caxias had a higher prevalence of HFI compared with the national prevalence $(30 \cdot 2 \%)$ and twice the prevalence of HFI compared with the state of Rio de Janeiro (21.9\%), where Duque de Caxias is located. The higher level of HFI in Duque de Caxias may be a result of the poverty in the region. In 2010, 6.3\% of the Duque de Caxias population lived below the poverty line; this proportion is more than twice the average for the state of Rio de Janeiro ${ }^{(48)}$. Nevertheless, large industries are concentrated in Duque de Caxias, and
Duque de Caxias has the second largest share in the state's gross domestic product ${ }^{(49)}$. Additionally, the primary centre of oil production in Rio de Janeiro is located in Campos Elíseos. However, the district has one of the lowest per capita incomes of Duque de Caxias and a high proportion of families living in poverty and experiencing $\mathrm{FI}^{(29)}$.

The present study also investigated perceived social support and obtained scores of 78.9-86.3 for social support dimensions on a 20 - to 100 -point scale and $79 \cdot 0$ for total social support on a 19- to 95-point scale. These scores are very similar to those obtained in the population in which the Brazilian version of the MOS-SSS was adapted and validated ${ }^{(40,47)}$. Although there is no specific cut-off point to define what would be a 'high'/'low' or a 'satisfactory'/'unsatisfactory' social support level, we consider the average scores found for Campos Elíseos families to be high, which reflects that individuals felt supported by their social networks in a way they could obtain some resources from them. However, lower scores for all dimensions of social support were observed for families with some HFI; this first signalled what the multinomial logistic regression then confirmed: the perceived availability of having someone to offer some support if needed may help vulnerable people to handle food shortages and to feel less food insecure.

The literature is scarce and controversial regarding our main finding of an independent association between 
social support and HFI. In a study analysing women and children under 3 years old from two ethnicities in rural Tanzania, Hadley et al. ${ }^{(50)}$ found that material support (the only social support dimension assessed) was inversely and independently associated with HFI. On the contrary, De Marco and Thorburn ${ }^{(51)}$ did not find evidence of an association between social support and HFI among Oregon (USA) residents. Other authors have qualitatively evaluated the participation of social support on facing adversities imposed by unfavourable living conditions that lead individuals to hunger. The coping strategies that were cited by the participants of these studies included seeking assistance from family, friends and neighbours for food or money, information ${ }^{(52,53)}$ and emotional support ${ }^{(52)}$; these results are consistent with the current study's findings of a positive contribution of social support for a qualitative and quantitative feeding. A study conducted among lowincome Puerto Rican families in Hartford (USA) ${ }^{(54)}$ also supports this finding. The latter study did not assess social support, but social networking based on participation in Latino church services and cultural events. Social networking could be considered a proxy of social support because it constitutes opportunities to experience and improve social support. The Hartford study concluded that participating in these events was strongly associated with FS.

In the present study, socio-economic and demographic factors had a stronger impact on HFI than did social support. In particular, family income had the main impact on HFI, which is reasonable given the poverty context in which the study population lives. These findings were expected based on previous local and national research that strongly suggested those most vulnerable to HFI usually have the lowest incomes, highest number of household residents, least years of education and worst access to clean water ${ }^{(16-18,29,31)}$. Even with small effect sizes, the independent and significant inverse association between social support and HFI indicates that this aspect of people's lives deserves to be better studied in the FI context. Social support should be considered when evaluating, monitoring and developing social policies that aim to attenuate or overcome HFI. In addition to seeking to understand how social support influences HFI, future research should also assess whether social support attenuates the impact of FI on negative health outcomes, which was apparent in Kollannoor-Samuel et al.'s ${ }^{(55)}$ study of low-income Latino adults in Hartford with type 2 diabetes.

Our findings also reflect how different dimensions of social support may influence HFI. Emotional support and informational support were particularly relevant for families with severe FI (families experiencing hunger). In this case, the feeling of having someone to trust and confide in would enhance an individual's sense of personal control over specific situations and would help to reduce his/her uncertainties about food. Additionally, having someone to offer advice, suggestions and information could play a fundamental role in problem solving and empowerment, which may act as important coping strategies for handling FI.
The results also show that affective support can especially benefit individuals who live with concerns about having enough food and experience some limits to food access, but not hunger. In this sense, by meeting basic human needs of love and affection and by making individuals feel cared for, esteemed and worthy, affective support can improve individuals' self-evaluation and alleviate the stressful situations that 'being concerned about or not being sure of having enough to feed the family' implies. Positive social interaction support was inversely associated with all HFI levels. This finding highlights the fact that having someone to relax and have fun with can help individuals in this socially vulnerable group face social vulnerability and hunger and feel less food insecure.

In the adjusted model, material social support was associated only with moderate FI. In fact, considering that the material support items evaluated by the Brazilian version of the MOS-SSS refer to the availability of support in general and daily activities ${ }^{(42,46,47)}$, it is plausible to think that families experiencing some limits to food access, especially limits in diet variability/quality, may benefit from having someone to help in meal preparation or in daily home activities. However, for individuals experiencing hunger, this may not be enough. The most important material support for families with severe FI may be directly related to obtaining food or the means to get enough food, such as relying on their social networks to borrow food or money, to make food exchanges, to receive food donations, or even to be able to dine at close relatives' or neighbours' homes. Unfortunately, the study did not evaluate this facet of material support.

Some limitations of the current study must be considered. The cross-sectional study design does not allow us to infer causality or to assess the temporal sequence of events. However, our empirical and theoretical knowledge about the study population allows us to find more plausible that lower levels of perceived social support lead to HFI, than HFI leads families to social isolation and lower social support. Future longitudinal studies would help to confirm this hypothesis and infer causality. Another limitation of the study concerns families' inclusion in the federal government's conditional cash transfer programme (Programa Bolsa Familia; PBF), which was not assessed. The PBF is designed to help families in poverty and extreme poverty conditions. It aims not only to immediately reduce poverty through cash transfers, but the PBF also endorses productive and social inclusion by including beneficiary families in complementary programmes that promote access to basic public services and rights, such as health care, education and social assistance ${ }^{(56,57)}$. These services may constitute opportunities for families to develop common bonds and social networks. The study was conducted in a low-income population in which a significant portion of the families may be PBF beneficiaries. Because we did not assess the inclusion of families in PBF, we could not assess how these formal social networks allowed families to cope with 
unfavourable living conditions, including HFI. However, to our knowledge, the present study is the first one to evaluate the association between social support and HFI among families in the metropolitan area of Rio de Janeiro. It is also the first study in Brazil to investigate this relationship using two scales of individual perceptions that were crossculturally adapted and validated for measuring these constructs in the Brazilian population.

\section{Conclusion}

The present work assessed the relationship between social support evaluated under individual perspectives and perceptions of access to food in families from a metropolitan area of Rio de Janeiro with a high prevalence of HFI. The results suggest that social support contributes to reduced HFI; this association is upheld even when variables that are historically related to the phenomenon are included. There are few studies about this topic, but there is a growing interest in the development of social policies against hunger in Brazil. Therefore, these results offer primary and relevant information for planning and organizing the participation of social relationships in a food and nutrition security context. The EBIA has already shown to be an instrument with strong potential to influence and improve governance in FS intervention in Brazil ${ }^{(58)}$. Indeed, these findings suggest that social support should be considered in tandem with EBIA as a way to address HFI. In this regard, strategies to strengthen social support in vulnerable communities should be developed and included in national efforts and existing social programmes to fight hunger and poverty.

\section{Acknowledgements}

Financial support: This study was supported by the National Research Council (CNPq; Grant Edital Universal, number 476344/2008-5) and Carlos Chagas Filho Research Support Foundation (FAPERJ; grant numbers E-26/110.785/ 2010 and E-26/103.296/2011). CNPq and the Carlos Chagas Filho Research Support Foundation had no role in the design, analysis or writing of this article. Conflict of interest: None. Authorship: G.S.I. participated in data collection, the manuscript concept, statistical analysis, and writing and revising the manuscript. R.S.-C. participated in the concept and design of the study, coordination and supervision of the data collection, and writing and revising the manuscript. Ethics of human subject participation: The research was approved by the Ethics Committee of the Federal University of Rio de Janeiro (number 73/2009; protocol number 01/2009).

\section{References}

1. Brasil (2006) Lei n. 11346 de 15 de setembro de 2006. Cria o Sistema Nacional de Segurança Alimentar e Nutricional - SISAN com vistas a assegurar o direito humano à alimentação adequada e dá outras providências. Diário Oficial da União, Brasília 2006 set. 18, Sec. 1:1.

2. Segall-Corrêa AM, Pérez-Escamilla R, Marin-Léon L et al. (2008) Evaluation of household food insecurity in Brazil: validity assessment in diverse sociocultural settings. In Iniciativa America Latina y Caribe Sin Hambre, Concurso redSAN 2007: Memoria artículos ganadores, pp. 80-101 [J Ortega, editor]. Santiago: Oficina Regional FAO-Chile; available at http://www.bvsde.paho.org/texcom/nutricion/ memredsan_3.pdf

3. Vozoris NT \& Tarasuk VS (2003) Household food insufficiency is associated with poorer health. J Nutr 133, 120-126.

4. Sullivan AF, Clark S, Pallin DJ et al. (2010) Food security, health, and medication expenditures of emergency department patients. J Emerg Med 38, 524-528.

5. Whitaker RC, Phillips SM \& Orzol SM (2006) Food insecurity and the risks of depression and anxiety in mothers and behavior problems in their preschool-aged children. Pediatrics 118, E859-E868.

6. Weigel MM, Armijos RX, Hall YP et al. (2007) The household food insecurity and health outcomes of US-Mexico border migrant and seasonal farmworkers. J Immigr Minor Health 3, 157-169.

7. Lent MD, Petrovic LE, Swanson JA et al. (2009) Maternal mental health and the persistence of food insecurity in poor rural families. J Health Care Poor Underserved 20, 645-661.

8. Hromi-Fiedler A, Bermúdez-Millán A, Segura-Pérez S et al. (2011) Household food insecurity is associated with depressive symptoms among low-income pregnant Latinas. Matern Child Nutr 4, 421-430.

9. Seligman HK, Bindman AB, Vittinghoff E et al. (2007) Food insecurity is associated with diabetes mellitus: results from the National Health Examination and Nutrition Examination Survey (NHANES) 1999-2002. J Gen Intern Med 22, 1018-1023.

10. Seligman HK, Laraia BA \& Kushel MB (2010) Food insecurity is associated with chronic disease among low-income NHANES participants. $J$ Nutr 140, 304-310.

11. Velásquez-Melendez G, Schlüssel MM, Brito AS et al. (2011) Mild but not light or severe food insecurity is associated with obesity among Brazilian women. J Nutr 141, 898-902.

12. Drewnowski A \& Specter SE (2004) Poverty and obesity: the role of energy density and energy costs. Am J Clin Nutr $\mathbf{7 9}$, 6-16.

13. Casey PH, Simpson PM, Gossett JM et al. (2006) The association of child and household food insecurity with childhood overweight status. Pediatrics 118, E1406-E1413.

14. McIntyre L, Glanville NT, Raine KD et al. (2006) Do lowincome lone mothers compromise their nutrition to feed their children? CMAJ 168, 686-691.

15. Antunes MM, Sichieri R \& Salles-Costa R (2010) Consumo alimentar de crianças menores de três anos residentes em área de alta prevalência de insegurança alimentar domiciliar. Cad Saude Publica 26, 1642-1650.

16. Ministério do Planejamento, Orçamento e Gestão \& Instituto Brasileirode Geografia e Estatística (2006) Pesquisa Nacional por Amostra de Domicílios. Segurança alimentar:2004. Rio de Janeiro: IBGE.

17. Brasil Ministério da Saúde, Centro Brasileiro de Análise e Planejamento (2008) Pesquisa nacional de demografia e saúde da criança e da mulber - PNDS 2006: Relatório Final. Brasília: Ministério da Saúde.

18. Ministério do Planejamento, Orçamento e Gestão \& Instituto Brasileiro de Geografia e Estatística (2010) Pesquisa Nacional por Amostra de Domicílios. Segurança alimentar: 2004/2009. Rio de Janeiro: IBGE. 
19. Kendall A, Olson CM \& Frongillo EA (1995) Validation of the Radimer/Cornell measures of hunger and food insecurity. J Nutr 125, 2793-2801.

20. Carlson SJ, Andrews MS \& Bickel GW (1999) Measuring food insecurity and hunger in the United States: development of a national benchmark measure and prevalence estimates. J Nutr 129, 2S Suppl., 510S-516S.

21. Bickel G, Nord M, Price C et al. (2000) Guide to Measuring Household Food Security, Revised 2000. Washington, DC: US Department of Agriculture, Food and Nutrition Service; available at http://www.fns.usda.gov/FSEC/FILES/FSGuide. pdf

22. Radimer KL \& Radimer KL (2002) Measurement of household food security in the USA and other industrialized countries. Public Health Nutr 5, 859-864.

23. Nord M, Andrews MS \& Carlson S (2009) Measuring Food Security in the United States: Household Food Security in the United States, 2008. Economic Research Report no. 83. Washington, DC: US Department of Agriculture, Economic Research Service; available at http://www.ers.usda.gov/ media/184956/err83_1_.pdf

24. Pérez-Escamilla R, Segall-Corrêa AM, Maranha LK et al. (2004) An adapted version of the US Department of Agriculture food insecurity module is a valid tool for assessing household food insecurity in Campinas, Brazil. J Nutr 134, 1923-1928.

25. Melgar-Quinonez HR, Nord M, Pérez-Escamilla R et al. (2008) Psychometric properties of a modified US-household food security survey module in Campinas, Brazil. Eur J Clin Nutr 62, 665-673.

26. Nord M (2007) Characteristics of Low-Income Households with Very Low Food Security: An Analysis of the USDA GPRA Food Security Indicator. Economic Information Bulletin no. 25. Washington, DC: US Department of Agriculture, Economic Research Service; available at http:// www.ers.usda.gov/media/196569/eib25_1_.pdf

27. Pimentel PG, Sichieri R \& Salles-Costa R (2009) Insegurança alimentar, condições socioeconômicas e indicadores antropométricos em crianças da Região Metropolitana do Rio de Janeiro/Brasil. R Bras Est Pop 26, 283-294.

28. Coleman-Jensen A, Nord M, Andrews M et al. (2012) Household Food Security in the United States in 2011. Economic Research Report no. 141. Washington, DC: US Department of Agriculture, Economic Research Service; available at http://www.ers.usda.gov/media/884525/err141. pdf

29. Salles-Costa R, Pereira RA, Vasconcellos MTL et al. (2008) Associação entre fatores socioeconômicos e insegurança alimentar: estudo de base populacional na Região Metropolitana do Rio de Janeiro, Brasil. Rev Nutr 21, Suppl., S99-S109.

30. Vianna RPT \& Segall-Corrêa AM (2008) Insegurança alimentar das famílias residentes em municípios do interior do estado da Paraíba, Brasil. Rev Nutr 21, Suppl., 111S-122S.

31. Panigassi G, Segall-Corrêa AM, Marin-Léon L et al. (2008) Insegurança alimentar como indicador de iniqüidade: análise de inquérito populacional. Cad Saude Publica 24, 2376-2384.

32. Burlandy L \& Salles-Costa R (2007) Segurança alimentar e nutricional: concepções e desenhos de investigação. In Epidemiologia Nutricional, pp. 485-501 [G Kac, R Sichieri and DP Gigante, editors]. Rio de Janeiro: Fiocruz/Atheneu.

33. Lemke S, Voster HH, Rensburg JV et al. (2003) Empowered women, social networks and the contribution of qualitative research: broadening our understanding of underlying causes for food and nutrition insecurity. Public Health Nutr 6, 759-764.

34. Martin KS, Rogers BL, Cook JT et al. (2004) Social capital is associated with decreased risk of hunger. Soc Sci Med 58, $2645-2654$.
35. Walker JL, Holben DH, Kropf ML et al. (2007) Household food insecurity is inversely associated with social capital and health in females from Special Supplemental Nutrition Program for Women, Infants, and Children households in Appalachian Ohio. J Am Diet Assoc 107, 1989-1993.

36. Kirkpatrick SI \& Tarasuk V (2010) Assessing the relevance of neighbourhood characteristics to the household food security of low-income Toronto families. Public Health Nutr 13, 1139-1148.

37. Due P, Holstein B, Lund R et al. (1999) Social relations: network, support and relational strain. Soc Sci Med 48, 661-673.

38. House JS (1987) Social support and social structure. Sociol Forum 2, 135-146.

39. Sherbourne CD \& Stewart AL (1991) The MOS social support survey. Soc Sci Med 32, 705-714.

40. Griep RH, Chor D, Faerstein E et al. (2003) Apoio social: confiabilidade teste-reteste de escala no Estudo Pró-Saúde. Cad Saude Publica 19, 625-634.

41. Cobb S (1976) Social support as a moderator of life stress. Psychosom Med 38, 300-314.

42. Lakey B \& Cohen S (2000) Social support theory and measurement. In Social Support Measurement and Interventions: A Guide for Health and Social Scientists, pp. 29-52 [S Cohen, LG Underwood and BH Gottlieb, editors]. New York: Oxford University Press.

43. Heaney CA \& Israel BA (2008) Social networks and social support. In Health Behavior and Health Education: Theory, Research and Practice, 4th ed., pp. 189-210 [K Glanz, BK Rimer and K Viswanath, editors]. San Francisco, CA: Jossey Bass.

44. Ministério do Planejamento, Orçamento e Gestão \& Instituto Brasileiro de Geografia e Estatística (2011) Censo Demográfico de 2010. Características da população e dos domicílios: Resultados do universo. Rio de Janeiro: IBGE.

45. National Research Council, Committee on National Statistics Division of Behavioral and Social Sciences and Education (2005) Measuring Food Insecurity and Hunger: Phase 1 Report. Washington, DC: The National Academies Press.

46. Chor D, Griep RH, Lopes C et al. (2001) Medidas de rede e apoio social no Estudo Pró-Saúde: pré-testes e estudo piloto. Cad Saude Publica 17, 887-896.

47. Griep RH, Chor D, Faerstein E et al. (2005) Validade de constructo de escala de apoio social do Medical Outcomes Study adaptada para o português no Estudo Pró-Saúde. Cad Saude Publica 21, 703-714.

48. Brasil Ministério de Desenvolvimento Social (2012) A Extrema Pobreza segundo Censo 2010. Relatórios de Informações Sociais. Brasília: Secretaria de Avaliação e Gestão da Informação; available at http://aplicacoes.mds. gov.br/ead/ri/carrega_pdf.php?rel=extrema_pobreza

49. Instituto Brasileiro de Geografia e Estatística (2012) Produto Interno Bruto dos Municípios2010. Rio de Janeiro: IBGE.

50. Hadley C, Mulder MB \& Fitzherbert E (2007) Seasonal food insecurity and perceived social support in rural Tanzania. Public Health Nutr 10, 544-551.

51. De Marco M \& Thorburn S (2009) The relationship between income and food insecurity among Oregon residents: does social support matter? Public Health Nutr 12, 2104-2112.

52. Ahluwalia IB, Dodds JM \& Baligh M (1998) Social support and coping behaviors of low-income families experiencing food insufficiency in North Carolina. Health Educ Behav 25, 599-612.

53. Kempson K, Keenan DP, Sadani PS et al. (2003) Maintaining food sufficiency: coping strategies identified by limitedresource individuals versus nutrition educators. J Nutr Educ Behav 35, 179-188.

54. Dhokarh R, Himmelgreen DA, Peng YK et al. (2011) Food insecurity is associated with acculturation and social networks in Puerto Rican households. J Nutr Educ Behav 43, 288-294. 
55. Kollannoor-Samuel G, Wagner J, Damio G et al. (2011) Social support modifies the association between household food insecurity and depression among Latinos with uncontrolled type 2 diabetes. J Immigr Minor Health 13, 982-989.

56. Brasil Ministério de Desenvolvimento Social (2014) Bolsa Família. http://www.mds.gov.br/bolsafamilia (accessed February 2014).
57. Oliveira VB (2012) Transferência de renda e segurança alimentar e nutricional: um olhar sobre Programa Bolsa Família. In Segurança alimentar e nutricional: Tecendo a rede de saberes, pp. 101-120 [OF Schneider, editor]. Petrópolis: DP et Alii Editora Ltda.

58. Pérez-Escamilla R (2012) Can experience-based household food security scales help improve food security governance? Glob Food Sec 1, 120-125. 